\title{
Histopathological Assessment of Fusarium pseudograminearum Colonization of Cereal Culms During Crown Rot Infections
}

Noel L. Knight and Mark W. Sutherland, Centre for Crop Health, Faculty of Health, Engineering and Sciences, University of Southern Queensland, Toowoomba, QLD, 4350, Australia

\begin{abstract}
Knight, N. L. and Sutherland, M. W. 2016. Histopathological assessment of Fusarium pseudograminearum colonization of cereal culms during crown rot infections. Plant Dis. 100:252-259.

Histopathological assessment of the crown rot pathogen Fusarium pseudograminearum was performed using fluorescence microscopy of culm tissues of six cereal genotypes grown in inoculated field conditions. Tissue samples were collected at 10, 16, and 22 weeks after planting (WAP). Colonization of culm tissues was initiated through epidermal penetration, most distinctly through stomatal apertures, and progressed into the parenchymatous hypoderm, which exhibited the discoloration used as the basis for visual assessment of disease. Hyphae spread from the culm base vertically through the tissues, initially via the hypoderm and pith cavity. Colonization of sclerified cells occurred later in the disease process. Both xylem and phloem tissues became colonized by 16 WAP in all

host genotypes, with colonization being less extensive in the more resistant genotypes. Culms displaying dead head symptoms revealed dense colonization in at least the first three internodes, with frequent xylem vessel and phloem cell occlusions. Paired living culms from the same plants exhibited less extensive colonization. These observations have revealed the ability of $F$. pseudograminearum to colonize all cell types of nodal and internodal sections, including vascular tissues, across all host genotypes. This study is the first detailed examination of the pattern of $F$. pseudograminearum colonization in adult hosts and indicates a potential vascular mechanism by which the effects of crown rot are produced.
\end{abstract}

Crown rot caused by Fusarium pseudograminearum O’Donnell \& T. Aoki (= F. graminearum group I = Gibberella coronicola $)$ is a serious disease of bread wheat (Triticum aestivum L.), durum wheat (T. turgidum L. var. durum), and barley (Hordeum vulgare L.) in Australia, North America, and many cereal-growing regions around the world (Burgess et al. 2001; Smiley et al. 2005). Fusarium crown rot symptoms are traditionally assessed in adult culms (stems) of field-grown cereals, based on the extent of basal browning (Dodman and Wildermuth 1987; Smiley et al. 2005; Wallwork et al. 2004). Although many studies have phenotypically screened host germplasm for potential resistance to crown rot (Bovill et al. 2006; Mitter et al. 2006; Wallwork et al. 2004; Wildermuth and McNamara 1994) or examined cultural practices which might limit crown rot severity (Backhouse 2006; Backhouse et al. 1997; Burgess et al. 1996; Evans et al. 2010; Kirkegaard et al. 2004), little is known about the colonization patterns of $F$. pseudograminearum during disease development in host culms in the field.

In a recent study, Knight and Sutherland (2012) examined the growth of $F$. pseudograminearum in hard white spring wheat seedling leaf sheaths, reporting that $F$. pseudograminearum colonizes leaf sheaths via stomata and produces penetration structures in order to cross cell walls. To understand the mechanisms by which the pathogen causes disease symptoms and subsequent yield loss in the field, examination of the colonization of culm tissues during culm elongation and seed head maturation in the field is required. In a parallel study, Knight and Sutherland (2015) have assessed F. pseudograminearum

Corresponding author: M. W. Sutherland;

E-mail: mark.sutherland@usq.edu.au

*The $\boldsymbol{e}$-Xtra logo stands for "electronic extra" and indicates that two supplementary figures are published online.

Accepted for publication 7 September 2015.

http://dx.doi.org/10.1094/PDIS-04-15-0476-RE

(C) 2016 The American Phytopathological Society biomass in infected cereal culms using a quantitative polymerase chain reaction (qPCR) technique and reported significant differences between genotypes in the extent of colonization and a strong correlation between fungal biomass and visual symptoms. The visual symptoms of crown rot-namely, internode discoloration and dead head (or white head) development-form the basis for the field selection of genotypes with greater resistance to crown rot disease (McKnight and Hart 1966; Purss 1966; Wallwork et al. 2004). Employing microscopic assessment and fungal biomass measurements will establish the infection processes by which these symptoms emerge, improving selection methods and providing clues regarding the strategies employed by host lines expressing superior resistance.

This study reports the first extensive microscopic observations of cereal culm tissues colonized by $F$. pseudograminearum during crown rot development. In order to adequately report on colonization, a selection of cereal genotypes of varying susceptibility was assessed 10,16 , and 22 weeks after planting (WAP) in the field. A parallel greenhouse experiment on two host genotypes was also conducted. Differences in cell types penetrated and patterns of colonization between genotypes or species and the extent of vertical colonization in the culm were investigated. The first microscopic examination of the dead head phenomenon was also performed, comparing the colonization of culms with dead heads (prematurely senescent culms) with the level of colonization in living (nonsenescent) culms from the same plant. In particular, the untested hypothesis that transpirational flow is disrupted during crown rot disease by xylem vessel colonization (Kirkegaard et al. 2004; Klein et al. 1991; Smiley 2009) was examined. Our observations indicate the need for further physiological investigation into the effect of colonization on both xylem and phloem function in the host.

\section{Materials and Methods}

Field trials. Field trials were conducted in 2009 at the Leslie Research Facility experimental farm at Wellcamp, Queensland, Australia. The field site preparation, planting, inoculum production, and inoculation were as described by Knight and Sutherland (2015). The field site had been maintained on a 3-year rotation. An initial year of 
fallow was followed by a crop of inoculated durum wheat ('EGA Bellaroi') which was incorporated at maturity. In the third year, the experimental field trial was inoculated at sowing. The inoculum of F. pseudograminearum, containing a mixture of aggressive Australian isolates (A03\#24, A05\#49, and A05\#54) grown on colonized millet (Pennisetum glaucum (L.) R. Br.) was produced by staff at the Leslie Research Facility (Toowoomba, Queensland) following the procedure reported by Percy et al. (2012) and delivered to each furrow at planting via a fertilizer applicator. Genotypes were planted as 2.5 - $\mathrm{m}$ single-row plots with $5 \mathrm{~g}$ of seed planted per plot at a depth of $5 \mathrm{~cm}$. Rows were spaced at $50 \mathrm{~cm}$. Inoculum was delivered at a rate of $2.5 \mathrm{~g} / \mathrm{m}$ in a band lying $1.5 \mathrm{~cm}$ above the seed. Due to a long history of crown rot research on this field site, it was assumed that numerous $F$. pseudograminearum isolates were present in addition to those in the inoculum.

The cereal genotypes assessed were chosen based on their range of crown rot resistance levels (Table 1). Two hard white spring wheat lines ('2-49' and 'Puseas'), one durum wheat (EGA Bellaroi), and one barley ('Grimmett') were included for detailed assessment, while two hard white spring bread wheat genotypes ('Sunland' and 'Vasco'), which were growing at the same site in a neighboring crown rot trial, were included to compare culms with and without dead heads from the same plant.

Plants of 2-49, Puseas, EGA Bellaroi, and Grimmett were collected from the Wellcamp field trials at 10, 16, and 22 WAP. The 10-, 16-, and 22-WAP time points approximately coincided with booting, early milk, and maturity growth stages, respectively. The bread wheat plants Sunland and Vasco were collected at 16 WAP when a high proportion of dead heads were observed. These were used for examination of culms with and without this visual symptom. Samples were stored at $-70^{\circ} \mathrm{C}$ before processing for microscopic investigation.

Greenhouse experiments. Greenhouse experiments were performed using the highly aggressive $F$. pseudograminearum isolate A03\#24, collected from Tara, Queensland. Seedling growth conditions, the production of fungal cultures, preparation of conidial suspensions, and the inoculation procedure were as described by Knight et al. (2012), with the following modifications. Seed of each of the wheat genotypes 2-49 and Puseas were planted into 5-liter pots (six pots per genotype, five seeds per pot) at a depth of $2.5 \mathrm{~cm}$ in soilless potting mix (Premium Hi-Retention growing medium; Power Blend). At 14 days after planting, the coleoptile of each plant was gently abraded $0.5 \mathrm{~cm}$ behind the tip with a sterile toothpick and inoculated while remaining vertical with a $6-\mu 1$ droplet of a $10^{6}$ conidia/ml suspension, after which seedlings were placed in a growth chamber in the dark for $48 \mathrm{~h}$ with two cycles of $25^{\circ} \mathrm{C}$ for $14 \mathrm{~h}$ followed by $15^{\circ} \mathrm{C}$ for $10 \mathrm{~h}$ at $100 \%$ relative humidity. Inoculated seedlings were then removed and grown in a temperature-controlled greenhouse at $24^{\circ} \mathrm{C}$ (day) and $15^{\circ} \mathrm{C}$ (night) and harvested 16 WAP.

Tissue preparation, staining, and microscopic observation. Transverse and longitudinal sections of culm tissues (both internodes and nodes) up to the fourth internode were produced by hand-sectioning using a microtome blade (S35; Feather). Fragile tissues such as heavily infected culms were hand-sectioned between two pieces of Parafilm, as described by Frohlich (1984). Culm sections did not require clearing and fixing for adequate staining. Samples were stained immediately after sectioning using the solophenyl flavine-based fluorescence method described by Knight and Sutherland (2011). Tissues were viewed under a fluorescence microscope using a UV-2A filter (excitation filter, 330 to $380 \mathrm{~nm}$; dichroic mirror, $400 \mathrm{~nm}$; barrier filter, 420 nm; Eclipse E600; Nikon). All images, except Figure 2, were captured using a digital camera (MicroPublishing 5.0 RTV digital camera; QImaging) used in combination with associated software (analysis; Soft Imaging System). Figure 2 was captured using a digital camera (DP26; Olympus) in conjunction with associated software (cellSens; Olympus). Culm anatomy and tissue colonization were recorded. Colonization of vascular bundles in culms of Puseas was recorded as hyphal presence in xylem or phloem tissues. In this study, subtending leaf sheaths were not examined.

Numerical labeling of nodes and internodes follow the pattern that internode " $n$ " is below node " $n$ " on the culm. The term "basal node region" is used to replace the ambiguous tissue term "crown".

\section{Results}

Culm morphology. The morphology and tissue structure of the culm are presented in Figures 1and 2. Epidermal cells with thick cell walls encase the culm tissue (Fig. 1A). In contrast, cells of the parenchymatous hypoderm are thin walled, and this tissue contains small intercellular spaces. The parenchymatous hypoderm became progressively less extensive from basal to upper internode tissues of the culm. This cell layer was generally absent from the fourth or fifth internode upward in the genotypes examined. It must be noted that descriptions in this study and, commonly, in crown rot disease literature number only those internodes and associated distal nodes which have expanded and do not include the multiple unexpanded internodes which remain within the crown region for the life of the organism. Sclerenchymatous hypoderm is composed of a layer of thick-walled cells with very few intercellular spaces. This layer frequently includes small vascular bundles within it or at its margins. Interior to the hypoderm, the ground parenchyma consists of large, thin-walled cells surrounding the majority of the vascular bundles. The vascular bundles containing xylem vessels, tracheids, and phloem sieve tube elements are encased by a bundle sheath layer. Central pith parenchyma cells are very thin walled, with large intercellular apoplastic spaces. Culm internode tissue colonized by $F$. pseudograminearum hyphae is shown in Figure 1B (stained aqua). Note that hyphae can be observed in the parenchymatous hypoderm, sclerenchymatous hypoderm, pith parenchyma, and vascular bundles, including both xylem vessels and phloem elements.

Tissue structure changed greatly as the transverse plane of view moved upward through a node from the distal margin of the pith cavity in the internode below (Supplementary Fig. S1), through the nodal pith plexus, to the zone where differentiation of leaf sheath and internodal tissues is evident above the node (Fig. 2). The pith parenchyma cells of the internode formed a single layer of very thick-walled parenchyma cells (cell wall thickness up to $17 \mu \mathrm{m}$; Supplementary Fig. S2A, C, D, and E) at the base of each node (pith plexus), with a further layer of thin-walled parenchyma cells (cell wall thickness approximately $3 \mu \mathrm{m}$ ) immediately above the plexus. Nodes were typically heavily sclerified and, around the level of formation of the pith plexus, the anastomosing vascular bundles included multiple smaller diameter xylem vessels (Supplementary Fig. S2B). Tissues resumed the typical internode structure above the anastomosing tissue of the pith plexus and the region of leaf trace formation (Supplementary Fig. S1F). The thickened leaf trace is located above the node, encircles the base of the internode, and forms the basal structure for typical leaf sheath tissue above. Visible structural differences between the cereal genotypes examined were not discernible.

Culm colonization. Colonization of the different cell layers and types was observed and recorded for multiple culms for each genotype

Table 1. Cereal hosts used to assess Fusarium pseudograminearum colonization, their adult plant crown rot resistance rating (APR), and the number of culms sectioned for microscopic assessment at 10, 16, and 22 weeks after planting (WAP)

\begin{tabular}{|c|c|c|c|c|c|}
\hline \multirow[b]{2}{*}{ Genotype } & \multirow[b]{2}{*}{$\mathbf{A P R} \mathbf{R}^{\mathbf{a}}$} & \multirow[b]{2}{*}{ Species } & \multicolumn{3}{|c|}{ Number of culms sectioned } \\
\hline & & & $10 \mathrm{WAP}$ & 16 WAP & 22 WAP \\
\hline $2-49$ & 7 & Triticum aestivum & 2 & 15 & 2 \\
\hline Grimmett & 4 & Hordeum vulgare & 4 & 3 & 2 \\
\hline Sunland & 3 & T. aestivum & - & $4^{b}$ & - \\
\hline Vasco & 2 & T. aestivum & - & $6^{b}$ & - \\
\hline Puseas & 2 & T. aestivum & 3 & 18 & 2 \\
\hline $\begin{array}{l}\text { EGA } \\
\text { Bellaroi }\end{array}$ & 1 & $\begin{array}{l}\text { T. turgidum } \\
\text { var. durum }\end{array}$ & 3 & 3 & 2 \\
\hline
\end{tabular}

a Resistance rating: 1 = very susceptible, 2 = susceptible, 3 = moderately susceptible to susceptible, $4=$ moderately susceptible, $5=$ moderately resistant to moderately susceptible, $6=$ moderately resistant, $7=$ resistant to moderately resistant, 8 = resistant, and $9=$ very resistant (Matthews et al. 2013; D. Herde, DAFFQ, personal communication). The APR rating is calculated from a range of factors, including incidence of infection, dead head formation, and discoloration.

b Culms of Sunland and Vasco included two and three plants, respectively, each with paired nonsenescent and senescent culms. 
(Table 1) at 10, 16, and 22 WAP, corresponding to Zadoks growth stages (GS) 40-49, GS 70-79, and GS 99 (harvest maturity) (Zadoks et al. 1974), respectively. As the infection progressed beyond the initial stages, all cell types and tissues within the culms were eventually penetrated, regardless of host genotype. Plants harvested at 10, 16, and 22 WAP demonstrated a general increase in colonization extent over time. The extent of this colonization varied with the susceptibility of the genotype.

10 WAP. Initial penetration of the epidermis appeared to occur near ground level in field-grown plants in regions lateral to subtending basal leaf sheaths, including internodes and secondary root traces, with hyphal proliferation commonly observed around emerging secondary roots. Penetration was achieved by appressoria-like swelling of hyphal tips. In some cases, infection may have occurred at a lower level through the subcrown internode (SCI) because hyphae were sometimes observed inside the pith but not in the outer cortex of the first internode. Hyphal penetration of internodes and initial lesion (discoloration) formation was also observed to occur at

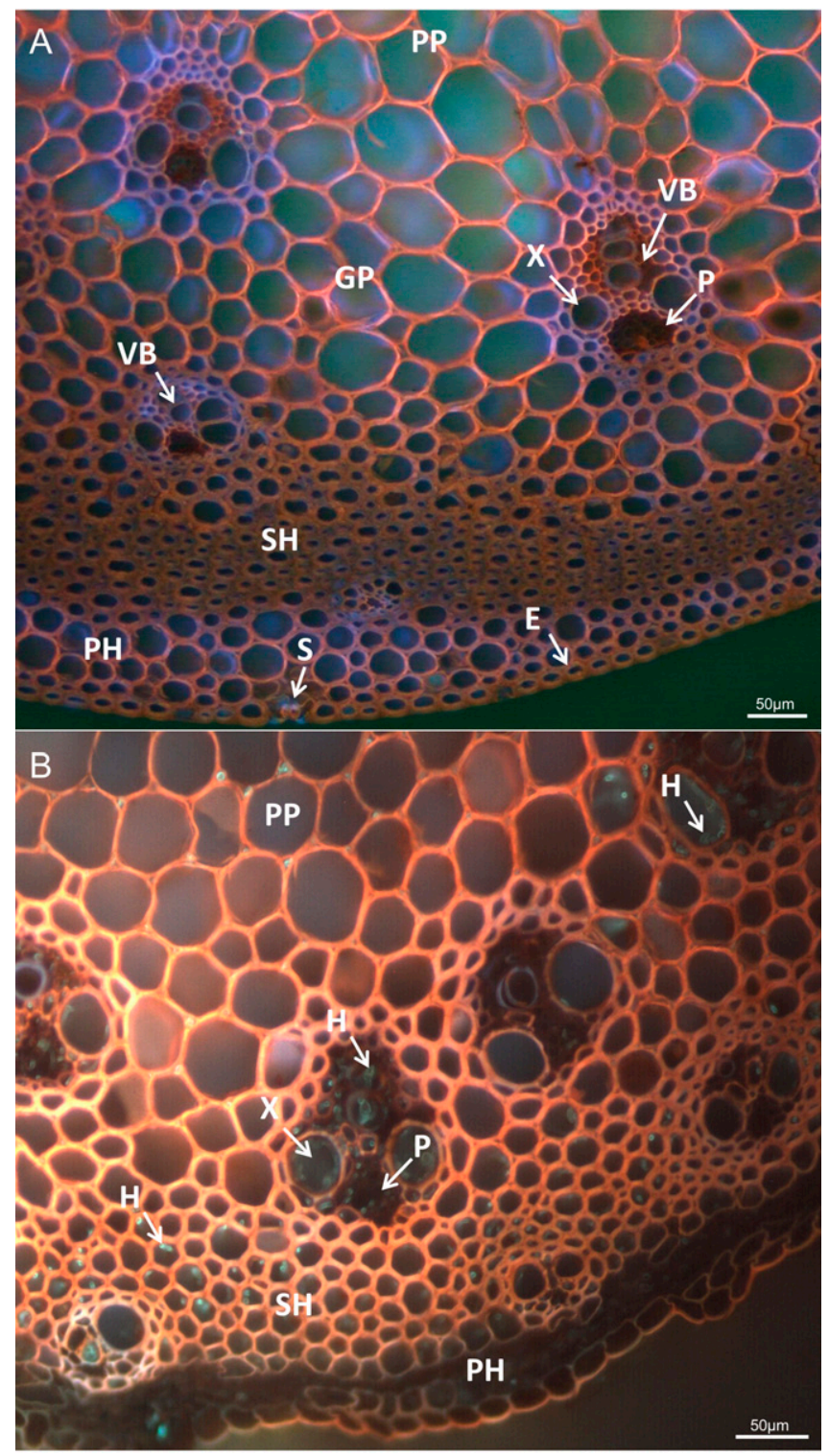

Fig. 1. Cell types in culm internode tissues (transverse section, TS) of $\mathbf{A}$, uncolonized and $\mathbf{B}$, colonized plants (Puseas). A, Culms consisted of epidermis (E) with stomata $(\mathrm{S})$, parenchymatous hypoderm $(\mathrm{PH})$, sclerenchymatous hypoderm $(\mathrm{SH})$, ground parenchyma (GP), vascular bundles (VB), with xylem (X) and phloem (P), and pith parenchyma (PP). B, Fusarium pseudograminearum hyphae (aqua fluorescence, H) colonizing the various tissues types of an internode, including the $\mathrm{PH}, \mathrm{SH}, \mathrm{PP}$, and VB, including both xylem vessels and phloem elements. The PH has lost fluorescence and become distorted. Tissues were stained using safranin and solophenyl flavine and viewed under ultraviolet light. stomata (Fig. 3A and B). In field-grown plants of 2-49 at $10 \mathrm{WAP}$, colonization was limited to the parenchymatous hypoderm in the basal nodal region below the first internode. In contrast, hyphae were observed in Puseas across all cell types of the culm cross-section up to the basal portion of the second internode, with the parenchymatous hypoderm and pith parenchyma containing two separate leading edges of colonization. Vascular bundles were observed to contain hyphae in both the xylem and phloem tissues up to the basal portion of the second internode. Grimmett barley showed only a limited infection of the parenchymatous hypoderm in the basal node region, similar to 249. EGA Bellaroi was infected across the basal node region, excluding the pith parenchyma, to the first internode, with the leading edge of infection in the parenchymatous hypoderm. There was limited colonization of the vascular bundles. The upper boundary of visual discoloration in each genotype coincided with the leading edge of hyphal colonization in the parenchymatous hypoderm.

16 WAP. Colonization remained limited in $2-49$, only reaching the second internode, with vascular bundles exhibiting colonization in the first internode in 3 of the 15 culms examined. Puseas became colonized up to the third internode across all the culm tissues, including the vascular bundles of each culm. Grimmett and EGA Bellaroi became colonized up to the third internode, with only the first and second internodes becoming colonized across all the tissues, including the vascular bundles. The leading edge of colonization in all genotypes was observed in the parenchymatous hypoderm and pith parenchyma. Samples of 2-49 and Puseas included tissues from both field and greenhouse experiments.

22 WAP. Culms had reached harvest maturity by this time. All four genotypes were colonized across the culm tissues up to the third

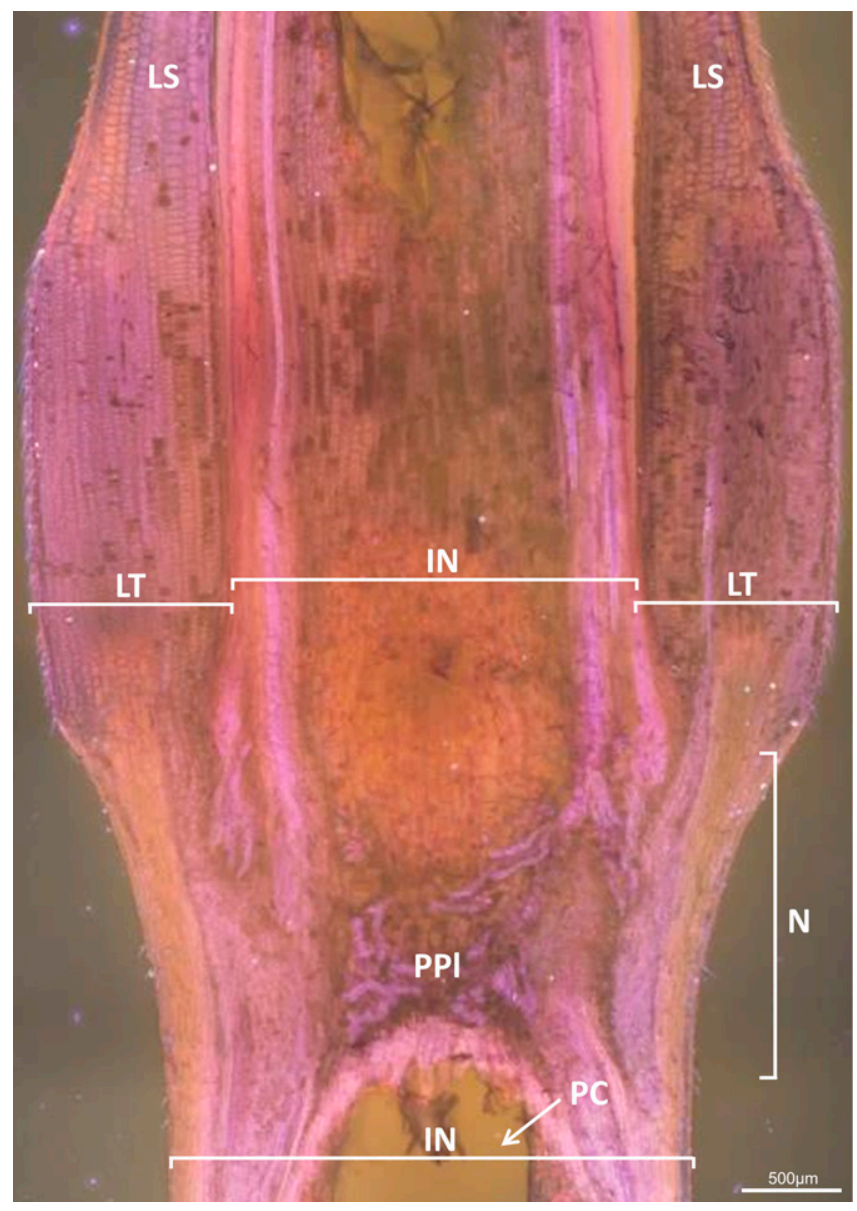

Fig. 2. Tissue types in a culm (longitudinal section) (Puseas). Culms consist of nodes (N) and internodes (IN). The internode below the node has a hollow pith cavity (PC). The nodal pith plexus (PPI) forms above the PC and consists of anastomosing vascular bundles, which separate into the distal internode and leaf trace (LT). The LT becomes typical leaf sheath (LS) tissue further up the culm. Tissues were stained using safranin and solophenyl flavine and viewed under ultraviolet light. 
internode, including vascular bundle colonization. Instances of hyphae with no fluorescence were observed at 22 WAP in the vascular bundles. Tissues of Puseas and EGA Bellaroi appeared more densely colonized by hyphae than 2-49 and Grimmett.

Observations on tissue colonization. Tissue colonization was assessed in both field- and greenhouse-grown plants. No differences in colonization patterns between experiments were recorded. Epidermal cells were predominantly intracellularly colonized (Fig. 3D). This was typically more prevalent in the basal tissues of the culm; that is, the first and second internodes. In some instances, hyphae were also observed to be in cells internal to the epidermis but not in the epidermal tissues (Fig. 3E). Hyphae were infrequently observed on the exterior surface of epidermal cells. Substomatal lacunae and lacunae in the parenchymatous hypoderm commonly supported dense hyphal growth (Fig. 3C).
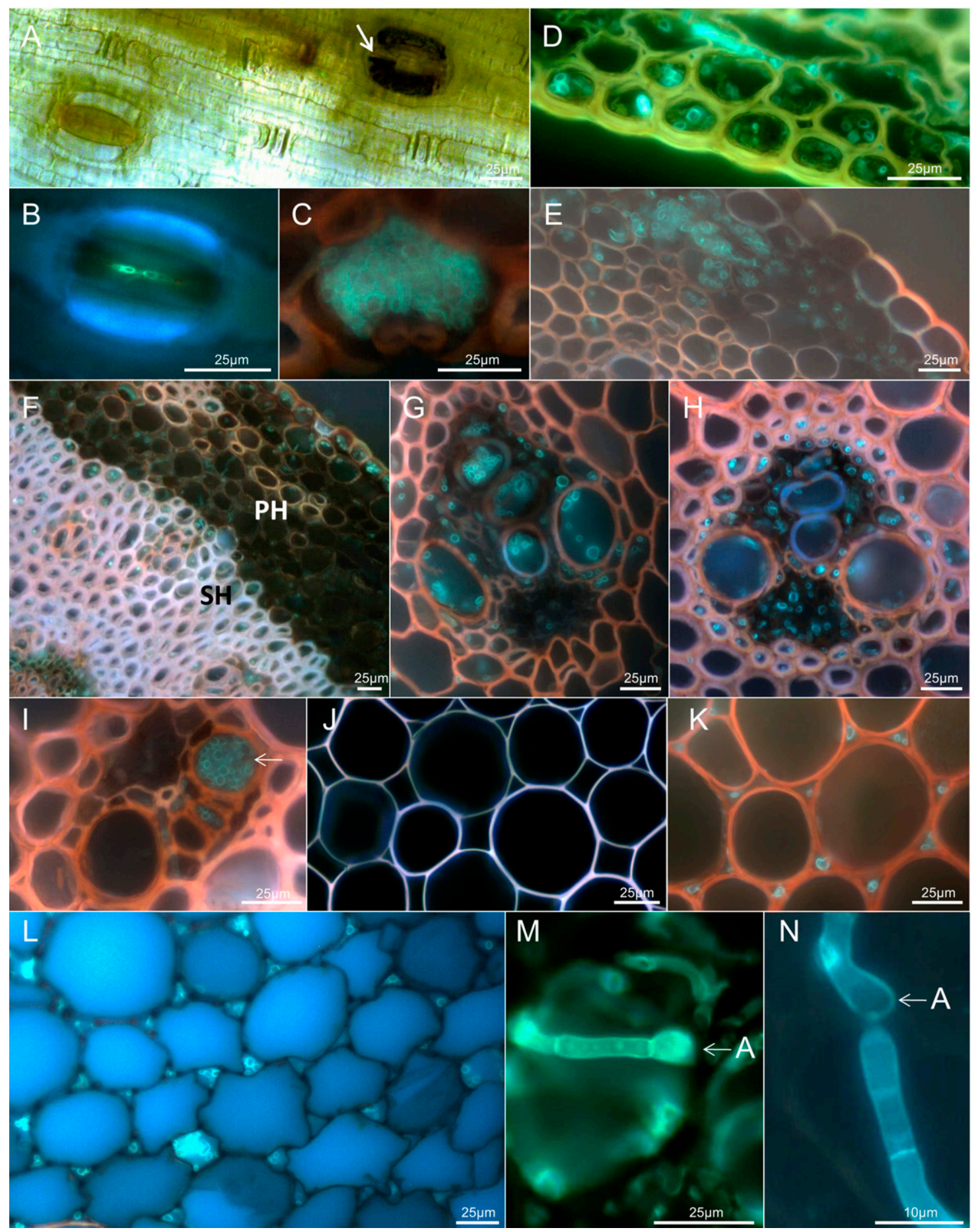

Fig. 3. Fusarium pseudograminearum colonization of internodal tissues. Tissues (excluding image A) were stained using safranin and solophenyl flavine and viewed under ultraviolet light. Image A was recorded under bright-field microscopy without staining. A, Discolored stomate (arrow) observed using bright-field microscopy (surface view [SV]; Sunland). B, Hyphae in the stomatal aperture of a stomate (SV; Sunland). C, Hyphae proliferating in the substomatal lacunae (transverse section [TS]; Puseas). D, Epidermal cells intracellularly colonized by hyphae (TS; Sunland). E, Colonization of the parenchymatous hypoderm (PH) adjacent to an uncolonized epidermal cell layer (TS; Puseas). F, PH cell layer exhibiting altered fluorescence after colonization while the sclerenchymatous hypoderm (SH) is similarly colonized but has not become discolored (TS; Bellaroi). G and H, Cells of the vascular bundles colonized in both the phloem and xylem tissues (TS; Puseas). I, Xylem vessel occluded by hyphae (indicated by an arrow; TS; Puseas). J, Pith parenchyma cells before colonization (TS; Vasco). K, Initial colonization of the pith parenchyma is by intercellular hyphae (TS; Puseas). L, Pith parenchyma cells after extended intercellular colonization (TS; Puseas). Cell walls have become distorted and exhibit altered fluorescence. M and $\mathbf{N}$, Penetration of cell walls facilitated by hyphal swellings and appressoria-like structures (A) (TS; Sunland and Puseas, respectively). 
Cells of the parenchymatous hypoderm were colonized predominantly by intracellular hyphae (Fig. 3E and F). These cells lost their wall fluorescence, became discolored, and were distorted in appearance (Figs. $1 \mathrm{~B}$ and $3 \mathrm{E}$ and $\mathrm{F}$ ). The visible brown discoloration used for visual disease rating coincided with the discoloration of this cell layer.

The sclerenchymatous hypoderm did not exhibit intra- or intercellular hyphae during initial stages of colonization and appeared to act as a barrier to lateral growth between the epidermal and pith regions. Subsequently, when predominantly intracellular hyphae were observed in the sclerenchymatous hypoderm, the cells did not exhibit altered fluorescence (Fig. 3F).

By 16 WAP, vascular bundles of the first internode were frequently (49\%, $n=224)$ colonized across all genotypes. Colonized cells of the vascular bundles did not exhibit altered fluorescence. The extent of colonization differed between individual vascular bundles, with xylem, phloem, and tracheids all potentially being colonized (Fig. 3G and $\mathrm{H}$ ). The parenchyma cells surrounding the large vascular bundles were both inter- and intracellularly colonized. No absolute preference for one vascular cell type was observed; however, the phloem in some bundles became more heavily colonized than the xylem vessels and tracheids. Large xylem vessels infrequently appeared to become occluded by hyphae (Fig. 3I). Hyphal presence at 16 WAP in the vascular bundles of the first internode in Puseas indicated that $39.7 \%$ of xylem and $40.8 \%$ of phloem bundles $(n=93)$ were colonized by at least one hyphae and, by 22 WAP, this increased to 68.1 and $59.1 \%$, respectively $(n=22)$. At maturity, infected phloem cells appeared to have disintegrated in some culms.

Initial hyphal colonization of the pith (Fig. 3J) was via the apoplast (Fig. 3K), with subsequent penetration of the cell walls. During intercellular colonization, these cells frequently became distorted and exhibited altered cell wall fluorescence (Fig. 3L). The pith cavity could support the dense growth of hyphae, which was particularly obvious in the basal internodes of culms exhibiting dead heads, where the pith cavity became filled by a dense mycelial mass.

Hyphae predominantly grew vertically up the plant, indicated by the high number of transversely cut hyphal strands in the transverse sections, especially in the intercellular spaces between cortical cells (Fig. 3K and L). Lateral growth was more frequent in parenchyma cells during intense colonization, with penetration of cell walls facilitated by hyphal swellings and appressoria-like structures that formed penetration pegs (Fig. 3M and N). Hyphal widths ranged from 2.1 to $7.2 \mu \mathrm{m}$. No significant difference in hyphal widths was observed in culm tissues between genotypes $(n=20)$.

Nodal tissue allowed variable colonization. As hyphae extend up the internode, they encounter nodal tissue, where the pith plexus is lined by a single layer of very thick-walled cells above which are the nodal anastomoses of the vascular tissues. Typical pith tissues then reappear at higher levels of the node. Hyphal growth was frequently dense beneath the pith plexus in the pith cavity (Fig. 4A). Penetration of the thick-walled pith plexus cells was not observed; however, the layers of cells above the pith plexus could be colonized, presumably by lateral growth of hyphae from peripheral ground tissues of the cortex. The vascular bundles passing through the node were also frequently colonized (Fig. 4B and C), with hyphae also present adjacent to vascular bundles in parenchyma and sclerenchyma tissues (Fig. 4D). The anatomy of nodal tissue is complex and tracing of hyphae through these tissues was challenging (Fig. 4E).

Hyphae were frequently observed to colonize the leaf trace forming from the first node and occasionally in the leaf trace from the second node (Fig. 4F). Colonization of the leaf trace was predominantly in the cortical cells but vascular bundles and associated stereome tissues were observed to be extensively colonized during severe infection (Fig. 4G).

Culm infection was not always uniform across individual tissue sections. A frequent observation was of intense patches of infection on one side of a culm, sometimes extending from the basal node region to the second internode. This coincided with the externally observed tissue browning. Although these patches showed hyphae in all cell types, hyphae were absent from the opposite side of the culm.
Colonization of these culms had progressed to the tissues above the transverse section via the pith and the hypoderm.

Assessment of culms with premature senescence (dead heads). Prematurely senescent culms were not observed in 2-49, Puseas, Grimmett, or EGA Bellaroi at any time point in these field and greenhouse trials. However, several plants of Sunland and Vasco, exhibiting prematurely senescent culms, were collected from a screening trial planted at the same site.

A comparison of colonization was performed at $16 \mathrm{WAP}$ between nonsenescent and senescent culms with heads of a similar size from the same wheat plant. Senescent culms were observed to be colonized across all the layers of tissues up to the second node, with colonization continuing up to the third node but predominantly restricted to the parenchymatous hypoderm, pith parenchyma, and vascular bundles. The pith cavity in the internodes of senescent culms also supported dense growth of hyphae (Fig. 5A), which frequently filled the pith cavity (Fig. 5B and C). Hyphae were not observed above the fifth internode and, at these upper margins of infection hyphae, were only observed in the pith. In some cases, large xylem vessels were completely occluded by hyphae (Fig. 5D and E) at the first and second internodes. Small vascular bundles in the sclerenchymatous hypoderm and large vascular bundles of the parenchymatous ground tissue were sometimes observed to be areas of intense hyphal growth, while cortical cells between the bundles appeared relatively free of hyphae (Fig. $5 \mathrm{~F}$ and $\mathrm{G}$ ). Nodal tissues, particularly the vascular bundles, were also heavily colonized.

Although the colonization within nonsenescent and senescent culms followed a similar pattern, the extent of colonization was less in the nonsenescent culms. Hyphae observed in the nonsenescent culms were also frequently in the vascular bundles. The height of colonization in nonsenescent culms was at least one whole internode and node lower than that observed in senescent culms.

\section{Discussion}

This is the first detailed microscopic assessment of the colonization of adult host plant tissues by $F$. pseudograminearum during crown rot development in the field and greenhouse, and follows an earlier study of greenhouse-grown seedling tissues (Knight and Sutherland 2012). Across four host cereal genotypes, a similar pathway of colonization was observed, whereby initial colonization occurred in the parenchymatous hypoderm and pith parenchyma cells, followed by lateral spread and colonization of the vascular bundles. Hyphal colonization and the associated reactions of the parenchymatous hypoderm cells were responsible for creating the brown discoloration used for disease rating. The progression of hyphae was traced up to the third internode in each genotype; however, differences in the density of colonization between genotypes were visually apparent.

Initial penetration and spread of hyphae occurred in both aboveground and belowground tissues. Penetration of internodes above ground level was predominantly via stomata, with penetration hyphae growing across from infected subtending leaf sheaths in close contact with the culm. This penetration of internodes by hyphae from leaf sheaths may also provide a pathway for the hyphae to bypass the nodal tissue and allow direct initial infection of the distal internode under favorable environmental conditions. In belowground infections, the initial penetration of the epidermal layer and adjacent hypoderm appears to be followed by rapid spread in the central tissues, shown by the occasional observation of pith colonization of the first internode without hypoderm colonization.

Belowground penetration can occur at the basal node region, coleoptile, SCI, and secondary root emergence points (Cook 1980; Taylor 1983). Taylor (1983) described colonization of these tissues, particularly the vascular tissues of the scutellum and SCI, and reported that spread of the hyphae occurred through the vascular bundles up into the basal node region and culm tissues. The current study supports the idea that initial colonization can occur below ground; however, initial spread of the fungus via the vascular tissues was not observed. $\mathrm{Xi}$ et al. (2008) reported similar observations using both $F$. pseudograminearum and $F$. graminearum. 
$F$. pseudograminearum colonization extended from the basal internode through nodal tissue, continuing progressively up the culm. Hyphal growth upward in the culm was most rapid through the thinwalled parenchyma cells of the hypoderm and pith, and in the hollow pith cavity. Hyphae initially invaded the intercellular spaces while intracellular growth generally occurred later in the infection process. Lateral penetration of the thick-walled, metabolically inactive sclerenchymatous cells was infrequent until culm senescence, suggesting that thickened cell walls initially provide greater resistance to penetration by $F$. pseudograminearum than the thinner walls of the parenchyma cells. This is consistent with the lack of penetration of silica cells in seedling leaf sheaths (Knight and Sutherland 2012).

Vertical hyphal growth through the pith cavity of the culm internode was interrupted by the layer of cells forming the pith plexus immediately below the nodal tissues. Hyphal growth continued around this barrier and through the complex tissue structure of the node (Chrysler 1906; Patrick 1972), which included colonization of the dense anastomosing vascular tissues.

At the nodes, it was also observed that, as the parenchymatous hypoderm of the internode below develops into the parenchyma of the leaf sheath at the node (Percival 1921), this transition directs hyphae from the parenchymatous hypoderm of the internode into the thickened base of the leaf sheath. This may be the origin of hyphal growth frequently observed on the exterior of the host above infected nodes at the thickened base of subtending leaf sheaths (Moore et al. 2005; Wallwork 2000).

Although no lateral penetration of vascular bundles was observed in internodal tissue, the anastomosing bundles in the nodes, including those in the crown, may provide an opportunity for this penetration to take place, though the complexity of nodal tissue potentially masked these events. The basal node region or crown (a region of lower nodes whose internodes do not elongate) contains the lowest four nodes during stem elongation, with the fifth either remaining in the crown or being slightly elevated (Herbek and Lee 2009; Patrick 1972). Therefore, the crown region contains many complexes of anastomosing vascular bundles. We hypothesize that colonization of the vascular tissues may be initiated around these areas of branching bundles. In a previous study, colonization of vascular tissues was not observed in seedling wheat leaf sheath tissue infected by $F$. pseudograminearum (Knight et al. 2012). In those experiments, colonization occurred on the leaf sheaths and was not yet present in the nodes or crown, which is consistent with the hypothesis that penetration of the vascular tissue occurs via nodal anastomoses.

Vascular colonization of both the xylem vessels and phloem sieve tubes of culms was common, with no obvious preference. Susceptible genotypes exhibited earlier and more extensive colonization of the vascular bundles compared with the partially resistant genotype 2-49. At maturity, differences in the degree of colonization between
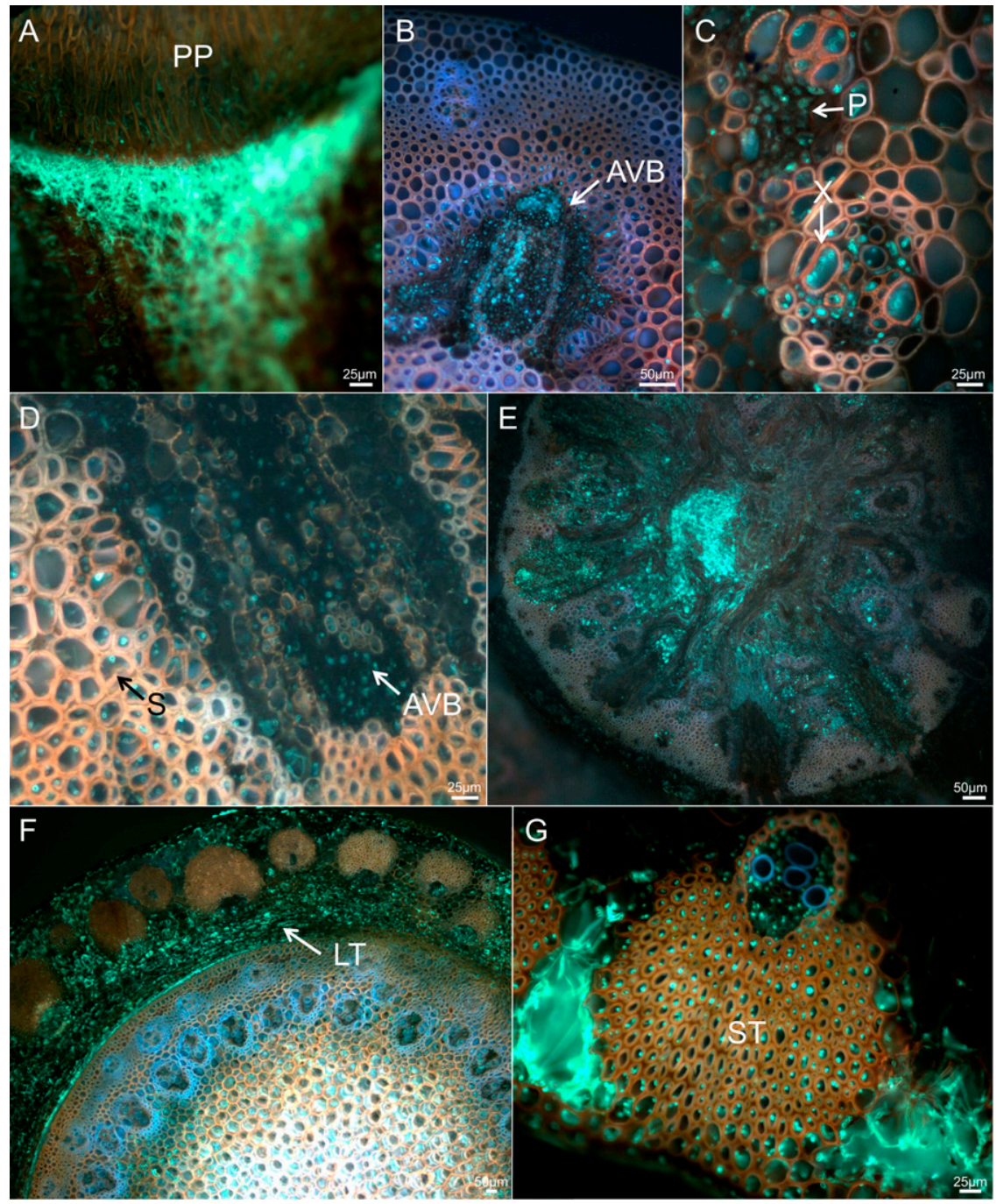

Fig. 4. Fusarium pseudograminearum colonization of nodal tissues at 16 weeks after planting. A, Dense hyphal growth in the pith cavity below the pith plexus (PP) (longitudinal section [LS]; Sunland). B, Extensive colonization of anastomosing vascular bundles (AVB) in a node (transverse section [TS]; Puseas). C, Colonization of both the xylem (X) and phloem (P) of vascular bundles at a node (TS; Puseas). D, Hyphae colonizing an AVB at a node adjacent to intracellularly colonized sclerenchyma (S) tissues (TS; Bellaroi). E, Extensive colonization across a nodal section (TS; Grimmett). F, Leaf trace (LT) colonization above a node (TS; Sunland). G, Extensive colonization of cortical, stereome (ST), and vascular tissues around an LT bundle (TS; Sunland). Tissues were stained using safranin and solophenyl flavine and viewed under ultraviolet light. 
partially resistant and susceptible genotypes are known to become less obvious in the lower internodes (Knight and Sutherland 2015). The comparison of nonsenescent and prematurely senescent culms at early milk development revealed intense colonization in the three basal internodes of the senescent culms, with frequent hyphal occlusions of xylem vessels and phloem tubes. Prematurely senescing culms exhibiting dead heads may represent instances in which multiple infection events have occurred around the culm base, leading to early colonization of a greater number of vascular bundles. Because these culms were senescent, it was difficult to determine whether the observed intense hyphal growth preceded or followed the death of the culm. Nonsenescent culms showed moderate vascular colonization along a shorter length of the culm, which demonstrates that vascular colonization in itself does not cause culm senescence. It is possible that vascular transport becomes significantly decreased when a longer portion or a greater proportion of the vascular tissue is colonized, potentially resulting in culm death. Colonization of the vascular bundles has the potential to cause the most debilitating effects of $F$. pseudograminearum infection. Although xylem vessels were rarely occluded before culm senescence, it is possible that their colonization by hyphae reduces their water- and ion-transporting ability. This water stress may stimulate $F$. pseudograminearum to aggressively colonize culm tissues, because it has been demonstrated that maximal growth by $F$. pseudograminearum requires progressively drier soil conditions (Beddis and Burgess 1992; Wearing and Burgess 1979). Equally significant is the colonization of the phloem, which may exacerbate the effect of xylem vessel colonization by limiting sugar transport to the roots, thus affecting water uptake and root development. This is supported by Purss (1966), who observed collapse of roots in plants with severe crown rot infections. Even more importantly, disruption of phloem function in these stressed plants is likely to impede delivery of sugars to the developing grain, and lead to the decreased grain size and reduced yields observed even in the absence of dead head formation.

Quantitative differences in qPCR estimations of fungal biomass between infected host genotypes of differing resistance have been reported in parallel studies on adult plants in the field (Knight and Sutherland 2015) and seedlings in the glasshouse (Knight et al.
2012). However, no differences in structural responses were discerned among genotypes during microscopy of infected seedling leaf sheaths (Knight and Sutherland 2012). Similarly, the variation in the extent of fungal colonization in this study, based on microscopy of adult tissues, could not be ascribed to any observable host structural characteristic or response, regardless of host species.

Spread of the fungus or, more accurately, its disease symptoms has been a major focus of crown rot research, with visual ratings of host resistance based on the percent discoloration of internodes and the distance that disease symptoms have spread up the culm (Malligan 2009; Wallwork et al. 2004; Wildermuth and McNamara 1994). The brown discoloration characteristic of crown rot infection is predominantly due to infection of the parenchymatous hypoderm, which exhibited a sharp drop in fluorescence and loss of cell integrity during colonization. The observed distortion of parenchyma cells during hyphal penetration has previously been reported for a range of Fusarium spp. by Pearson (1931), Taylor (1983), and Xi et al. (2008). Although the toxin deoxynivalenol is known to be produced by F. pseudograminearum (Mudge et al. 2006), the strong correlation between visual discoloration and fungal biomass reported by Knight et al. (2012) and Knight and Sutherland (2015) and the lack of symptom expression away from direct fungal colonization suggest that any metabolite released by $F$. pseudograminearum has only localized effects on symptom development.

A disease rating system based on discoloration of the parenchymatous hypoderm also explains why visual discoloration is predominantly seen on the basal three to four internodes of a culm. The thickness of the parenchymatous hypoderm is frequently reduced above the third internode and, because the sclerenchymatous hypoderm, which may instead be present, does not become colonized or discolored as readily, symptom development in the hypoderm and, thus, visual ratings would also be reduced. In higher portions of a culm, parenchymatous hypoderm was not present. For example, culms of Puseas and EGA Bellaroi lacked parenchymatous hypoderm from the fourth or fifth internode upward, and no discoloration was observed in these portions. In these instances, hyphae were still observed in the pith. This suggests a limitation of current visual rating procedures as an indication of the extent of spread of infection in

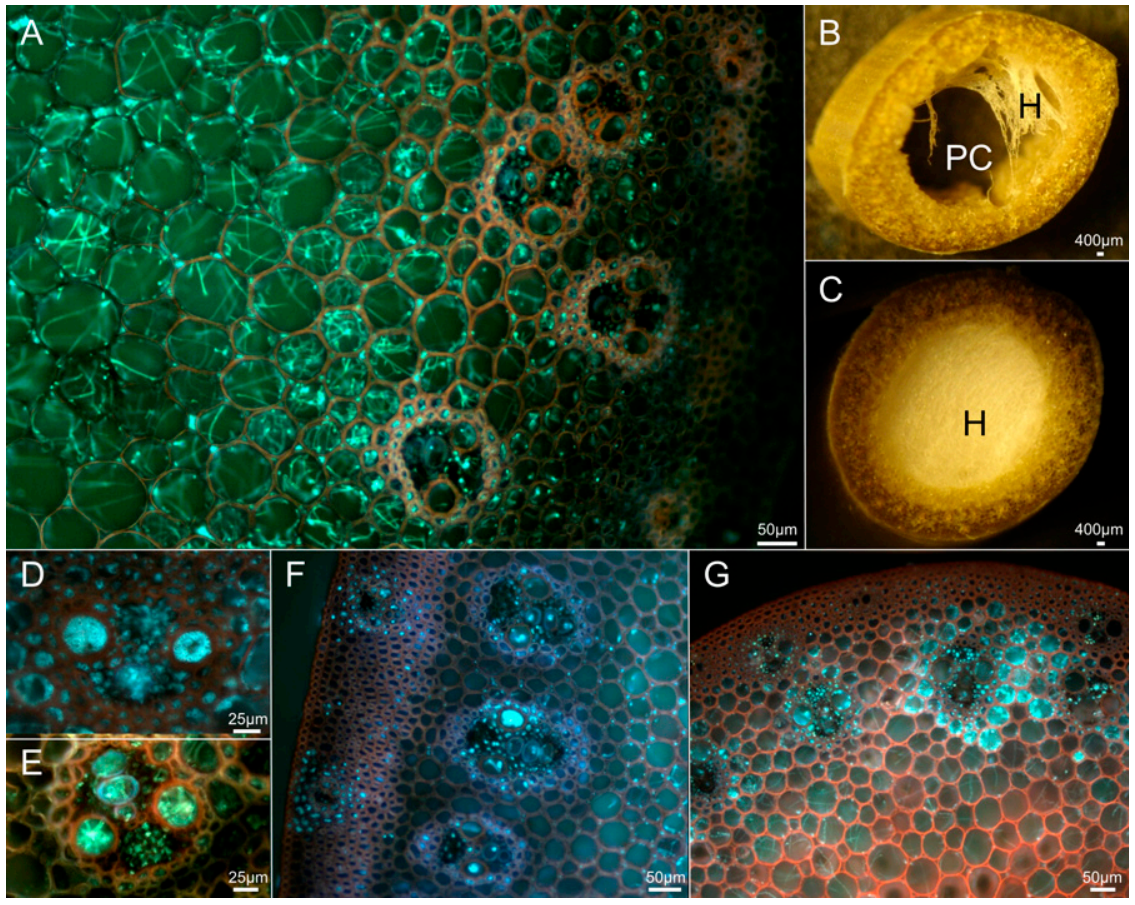

Fig. 5. Observations on infections of prematurely senescent culms (dead heads) at 16 weeks after planting. A, Extensive colonization across all tissues of an internode (transverse section [TS]; Sunland). B, Hyphae (H) proliferating in the pith cavity (PC) of an internode (TS; Sunland). C, Hyphae (H) filling the PC of an internode (TS; Sunland). D and E, Occlusion of large xylem vessels and extensive colonization of phloem tubes of vascular bundles (TS; Vasco). F and G, Small vascular bundles in the sclerenchymatous hypoderm and large vascular bundles exhibiting intense hyphal growth (TS; Vasco). Tissues were stained using safranin and solophenyl flavine and viewed under ultraviolet light. 
fully extended adult culms and warrants investigation of distal tissues further up the culm during disease development.

This study reports the first detailed examination of the growth of $F$. pseudograminearum in adult host tissues and has indicated that infection of the parenchymatous hypoderm is predominantly responsible for the visual discoloration used in traditional disease rating systems. Most importantly, it has been revealed that both phloem and xylem tissues can be colonized during crown rot disease. The observed colonization of xylem tissues is consistent with the hypothesis that disruption of transpiration contributes to loss of grain yield and dead head formation, while the accompanying infection of phloem elements also suggests that sugar transport for root function and grain development may be compromised in the host. These results highlight the need for further research into the physiological responses of cereals to this pathogen.

\section{Acknowledgments}

We thank our colleague A. Martin for her critical reading of the manuscript and D. Herde and C. Percy (Queensland Department of Agriculture Forestry and Fisheries) for providing the field-grown materials. Financial support for this project was provided by the Grains Research and Development Corporation. N. Knight acknowledges the support of an Australian Postgraduate Award.

\section{Literature Cited}

Backhouse, D. 2006. Forecasting the risk of crown rot between successive wheat crops. Aust. J. Exp. Agric. 46:1499-1506.

Backhouse, D., Burgess, L. W., Swan, L. J., and Esdaile, R. J. 1997. Crown rot of cereals in conservation farming systems. Pages 79-82 in: Proc. Farm. Syst. Conf. Moree, NSW, Australia.

Beddis, A. L., and Burgess, L. W. 1992. The influence of plant water stress on infection and colonisation of wheat seedlings by Fusarium graminearum group 1. Phytopathology 82:78-83.

Bovill, W., Ma, W., Ritter, K., Collard, B., Davis, M., Wildermuth, G., and Sutherland, M. 2006. Identification of novel QTL for resistance to crown rot in the doubled haploid wheat population 'W21MMT70' $\times$ 'Mendos'. Plant Breed. 125:538-543.

Burgess, L. W., Backhouse, D., Summerell, B. A., and Swan, L. J. 2001. Crown rot of wheat. Pages 271-294 in: Fusarium: Paul E. Nelson Memorial Symposium. B. Summerell, J. Leslie, D. Backhouse, W. Bryden, and L. Burgess, eds. American Phytopathological Society, St. Paul, MN.

Burgess, L. W., Backhouse, D., Swan, L. J., and Esdaile, R. J. 1996. Control of Fusarium crown rot of wheat by late stubble burning and rotation with sorghum. Australas. Plant Pathol. 25:229-233.

Chrysler, M. A. 1906. The nodes of grasses. Bot. Gaz. 41:1-16.

Cook, R. 1980. Fusarium foot rot of wheat and its control in the Pacific northwest. Plant Dis. 64:1061-1066.

Dodman, R. L., and Wildermuth, G. B. 1987. Inoculation methods for assessing resistance in wheat to crown rot caused by Fusarium graminearum group 1. Aust. J. Agric. Res. 38:473-486.

Evans, M. L., Hollaway, G. J., Dennis, J. I., Correll, R., and Wallwork, H. 2010. Crop sequence as a tool for managing populations of Fusarium pseudograminearum and F. culmorum in south-eastern Australia. Australas. Plant Pathol. 39:376-382.

Frohlich, M. W. 1984. Freehand sectioning with Parafilm. Stain Technol. 59: 61-62.

Herbek, J., and Lee, C. 2009. A Comprehensive Guide to Wheat Management in Kentucky. University of Kentucky Grain Crops Extension, Lexington.

Kirkegaard, J. A., Simpfendorfer, S., Holland, J., Bambach, R., Moore, K. J., and Rebetzke, G. J. 2004. Effect of previous crops on crown rot and yield of durum and bread wheat in northern NSW. Aust. J. Agric. Res. 55: 321-334.
Klein, T. A., Burgess, L. W., and Ellison, F. W. 1991. The incidence and spatial patterns of wheat plants infected by Fusarium graminearum group 1 and the effect of crown rot on yield. Aust. J. Agric. Res. 42:399-407.

Knight, N. L., Martin, A., Sutherland, M. W., and Herde, D. J. 2012. Assessment of infection by Fusarium pseudograminearum in wheat seedling tissues using quantitative PCR and a visual discoloration scale. Plant Dis. 96:1661-1669.

Knight, N. L., and Sutherland, M. W. 2011. A rapid differential staining technique for Fusarium pseudograminearum in cereal tissues during crown rot infections. Plant Pathol. 60:1140-1143.

Knight, N. L., and Sutherland, M. W. 2012. Histopathological assessment of wheat seedling tissues infected by Fusarium pseudograminearum. Plant Pathol. 62 679-687.

Knight, N. L., and Sutherland, M. W. 2015. Culm discolouration as an indicator of Fusarium pseudograminearum biomass. Australas. Plant Pathol. 44:319-326.

Malligan, C. D. 2009. Crown rot (Fusarium pseudograminearum) symptom development and pathogen spread in wheat genotypes with varying disease resistance. Ph.D. thesis, University of Southern Queensland, Toowoomba, QLD, Australia.

Matthews, P., McCafferey, D., and Jenkins, L. 2013. Winter crop variety sowing guide. Department of Primary Industries, NSW, Australia.

McKnight, T., and Hart, J. 1966. Some field observations on crown rot disease of whea caused by Fusarium graminearum. Queensl. J. Agric. Anim. Sci. 23:373-378.

Mitter, V., Zhang, M. C., Liu, C. J., Ghosh, R., Ghosh, M., and Chakraborty, S. 2006. A high-throughput glasshouse bioassay to detect crown rot resistance in wheat germplasm. Plant Pathol. 55:433-441.

Moore, K., Manning, B., Simpfendorfer, S., and Verrell, A. 2005. Root and Crown Diseases of Wheat and Barley. NSW Department of Primary Industries, Tamworth, NSW, Australia.

Mudge, A. M., Dill-Macky, R., Dong, Y., Gardiner, D. M., White, R. G., and Manners, J. M. 2006. A role for the mycotoxin deoxynivalenol in stem colonisation during crown rot disease of wheat caused by Fusarium graminearum and Fusarium pseudograminearum. Physiol. Mol. Plant Pathol. 69:73-85.

Patrick, J. W. 1972. Vascular system of the stem of the wheat plant I. Mature state Aust. J. Bot. 20:49-63.

Pearson, N. 1931. Parasitism of Gibberella saubinetti on corn seedlings. J. Agric Res. 43:569-596.

Percival, J. 1921. The Wheat Plant: A Monograph. Duckworth and Co, London.

Percy, C. D., Wildemuth, G. B., and Sutherland, M. W. 2012. Symptom development proceeds at different rates in susceptible and partially resistant cereal seedlings infected with Fusarium pseudograminearum. Australas. Plant Pathol. 41:621-631.

Purss, G. S. 1966. Studies of varietal resistance to crown rot of wheat caused by Fusarium graminearum Schw. Queensl. J. Agric. Anim. Sci. 23:475-498.

Smiley, R. W. 2009. Water and temperature parameters associated with winter wheat diseases caused by soilborne pathogens. Plant Dis. 93:73-80.

Smiley, R. W., Gourlie, J. A., Easley, S. A., Patterson, L.-M., and Whittaker, R. G. 2005. Crop damage estimates for crown rot of wheat and barley in the Pacific northwest. Plant Dis. 89:595-604.

Taylor, P. W. J. 1983. The influence of soil moisture on infection and colonisation of wheat by Fusarium graminearum group 1. M.Sc. thesis, The University of Sydney, Sydney, NSW, Australia.

Wallwork, H. 2000. Cereal Root and Crown Diseases. Grains Research and Development Corporation, Kingston, ACT, Australia.

Wallwork, H., Butt, M., Cheong, J. P. E., and Williams, K. J. 2004. Resistance to crown rot in wheat identified through an improved method for screening adult plants. Australas. Plant Pathol. 33:1-7.

Wearing, A. H., and Burgess, L. W. 1979. Water potential and the saprophytic growth of Fusarium roseum "Graminearum". Soil Biol. Biochem. 11:661-667.

Wildermuth, G. B., and McNamara, R. B. 1994. Testing wheat seedlings for resistance to crown rot caused by Fusarium graminearum group 1. Plant Dis. 78:949-953.

Xi, K., Turkington, T. K., and Chen, M. H. 2008. Systemic stem infection by Fusarium species in barley and wheat. Can. J. Plant Pathol. 30:588-594.

Zadoks, J. C., Chang, T. T., and Konzak, C. F. 1974. A decimal code for the growth stages of cereals. Weed Res. 14:415-421. 